\title{
Cold agglutinins in haemophiliac boys infected with HIV
}

\author{
P H B Bolton-Maggs, P D Rogan, J K M Duguid, K J Mutton, L M Ball
}

\begin{abstract}
Eleven haemophiliac boys infected with HIV were screened for irregular red cell antibodies and were compared with nine haemophiliac boys who did not have antibodies to HIV. Seven $(64 \%)$ of the children who had antibodies to HIV also had cold agglutinins, mostly of anti-I specificity, compared with one $(11 \%)$ of those who did not have antibodies to HIV. The children with antibodies to HIV and cold agglutinins had a significantly increased mean IgM concentration. The presence of cold agglutinins was not correlated with T4 lymphocyte count, symptoms of HIV infection, serum $\beta_{2}$ microglobulin concentrations, concentrations of IgG or IgA, or with the evidence of past infection with cytomegalovirus or Epstein-Barr virus.
\end{abstract}

Disturbances of immune function with hyperglobulinaemia and polyclonal activation of B cells are a feature of HIV infection. ${ }^{1}$ Several autoantibodies have been described in infected patients including a variety of red cell antibodies. ${ }^{2}$ These are usually of little clinical importance, although autoimmune haemolytic anaemia has been reported. ${ }^{3}$ The presence of red cell antibodies may, however, cause problems in blood grouping and cross matching for patients requiring transfusion.

In this study a group of 11 haemophiliac children infected with HIV were screened for irregular red cell antibodies, and were compared with a group of nine HIV antibody negative haemophiliac children. Both groups had been treated with clotting factor concentrates.

Royal Liverpool Children's Hospital, Alder Hey, Liverpool P H B Bolton-Maggs L M Ball

Mersey Regional Blood Transfusion Centre, Liverpool

P D Rogan

J K M Duguid

Public Health

Laboratory,

Fazakerley Hospital, Liverpool

K J Mutton

Correspondence to:

Dr P H B Bolton-Maggs,

Department of Haematolog

Royal Liverpool Hospital,

Prescot Street,

Liverpool L7 8XP.

Accepted 16 January 1991

(ArchDisChild 1991;66:732-733)

\section{Patients and methods}

All haemophiliac children infected with HIV (11 boys aged 5-15 years) who were registered at Mersey regional paediatric haemophilia centre were included in the study. A sample of 5 $\mathrm{ml}$ clotted blood was taken, and a further $2 \mathrm{ml}$ sample was placed in EDTA as part of the routine blood sampling at each visit to the clinic. The control group of patients comprised nine boys aged 2-18 years with haemophilia A or $B$ who were attending the clinic and who had received treatment with clotting factor concentrates but who were not infected with HIV, and from whom blood was being taken for regular monitoring.

Irregular red cell antibodies were sought by the indirect antiglobulin test, and enzyme and saline techniques at several temperatures using standard methods. ${ }^{4}$ Direct antiglobulin testing was also done. Past cytomegalovirus infection was detected by the presence of antibodies using latex agglutination (CMV-Scan, BectonDickinson) and IgG ELISA (Captia CMV-G, Mercia Diagnostics). Epstein-Barr virus viral capsid antigen IgG antibodies were detected by immunofluorescence using P3 HR1 cells. ${ }^{5} \mathrm{~T}$ cell subsets were measured in all patients by flow cytometry using a Coulter Electronics system. Serum $\beta_{2}$ microglobulin concentrations were measured by an ELISA (MELISA, Walker Diagnostics).

\section{Results}

Seven of the 11 children infected with HIV (64\%) had cold agglutinins in the serum compared with one of nine $(11 \%)$ in the control group. The cold agglutinins were of anti-I specificity in all children except one. The difference between these group is high significant $\chi^{2}=$ $6 \cdot 455,1 \mathrm{df}, 95 \%$ confidence interval $(\mathrm{CI})$.

All patients and controls had negative direct antiglobulin tests except for one child who was positive for HIV.

The presence of cold agglutinins in those patients who were positive for HIV did not correlate with mean $\mathrm{T} 4$ lymphocyte count, or serum $\beta_{2}$ microglobulin concentrations. Mean concentrations of immunoglobulins of all classes were increased in those children positive for HIV, but only for IgM was there a significant difference between the children positive for HIV who had cold agglutinins (mean IgM $2 \cdot 1$ $\mathrm{g} / \mathrm{l}$ ) and those who did not (mean $\operatorname{IgM} 1 \cdot 1 \mathrm{~g} / \mathrm{l}$, $\mathrm{p}=0.036$ ).

The incidence of antibodies to cytomegalovirus (2/11) and Epstein-Barr virus (9/11) was not increased in patients with cold agglutinins compared with those without (1/9 with antibodies to cytomegalovirus, and 8/9 with antibodies to Epstein-Barr virus).

One child positive for HIV had cold agglutinins the specificity of which could not be determined, and he also had a positive direct antiglobulin test as a result of coating with the complement components C3 and C3d. This child did not differ from the rest of the children who were positive for HIV in respect of the other variables.

\section{Discussion}

HIV infection is accompanied by a variety of disturbances of immune function including polyclonal B cell activation with raised immunoglobulin concentrations ${ }^{1}$ and autoimmune phenomena. Red cell antibodies have been reported, but only rarely with any apparent clinical effects. ${ }^{3}$ Anaemia is common in 
HIV infection, but immune haemolysis is not a significant cause. In this group of children positive for HIV we found a significant incidence of cold agglutinins of anti-I specificity compared with a group of HIV antibody negative haemophiliac children. Cold agglutinins are usually of IgM class, and this is consistent with our finding of raised IgM concentrations in the children with cold agglutinins. Cold agglutinins have been described in adult homosexual patients positive for $\mathrm{HIV},{ }^{26}$ and most commonly in those with symptoms related to the HIV infection. We found no association, however, between cold agglutinins and symptoms related to HIV infection.

Infective agents can cause sensitisation to red cells; both Epstein-Barr virus and cytomegalovirus infection are associated with the development of cold agglutinins. There were no differences between the two groups of patients in the incidence of seropositivity for cytomegalovirus or Epstein-Barr virus. It is likely therefore that the cold agglutinins in our patients were associated with the HIV infection itself.

Though six of our seven patients with cold agglutinins had anti-I, the other was unique in having cold agglutinins of undetermined specificity. He also had a positive direct antiglobulin as a result of coating with complement components, and he is transfusion dependent. His anaemia has only developed since starting therapy with azidothymidine, however, and does not seem to be caused by haemolysis as he has no reticulocytosis nor increase in his serum bilirubin concentration.

A single case of haemolytic anaemia associated with HIV infection which was associated with cold agglutinins has been reported and, unusually for cold antibodies, the patient responded well to treatment with steroids. ${ }^{3}$ None of our patients had symptoms related to the cold agglutinins but we had difficulty in cross matching until the antibodies had been identified, which led to delay in providing compatible blood. Transfusions have been uneventful since then.

We can find no other reports of cold agglutinins in children with HIV infection. This group differs from previously described adult patients in that they have a high incidence of anti-I.

1 Falloon J, Eddy J, Wiener L, Pizzo PA. Human immunodeficiency virus infection in children. $\mathcal{F}$ Pediatr 1989;114 $1-30$.

2 McGinniss MH, Macher AM, Rook AH, Alter HJ. Red cell autoantibodies in patients with acquired immune deficiency syndrome. Transfusion 1986;26:405-9.

3 Puppo F, Torresin A, Lotti G, Balleari E, Orlando G, Indiveri $\mathbf{F}$. Autoimmune hemolytic anemia and human immunodeficiency virus (HIV) infection. Ann Intern Med 1988;109:249-50.

4 Petz LD, Garratty G. The serologic investigation of autoimmune hemolytic anemia. Acquired immune hemolytic anemias. London: Churchill Livingstone, 1980:139-84.

5 Lennette EH, Schmidt NJ. Diagnostic procedures for viral rickettsial and chlamydial infections. 5th Ed. Washington American Public Health Association, 1979:453-9.

6 Pruzanski W, Roelcke D, Donnelly E, Lui L-C. Persistent cold agglutinins in AIDS and related disorders. Acto Haematol 1986;75:171-3. 